\title{
Vocational Training in Nursing: Advances Curriculum and Innovations in Educational Projects
}

Maryldes Lucena Bezerra de Oliveira1,2, Sabrina Alaide Alves Amorim¹, José Lucas Souza Ramos³, Cintia de Lima Garcia1,2, Hermes Melo Teixeira Batista ${ }^{2}$, Andre Luis Sant'anna4, Aretha Feitosa de Araújo5, José Maria Ximenes Guimarães ${ }^{5}$, Cicero Vagner Lucena de Sousa ${ }^{2}$, Sophia Cornbluth Szarfarc ${ }^{2}$, Gustavo Carreiro Pinasco 3

\section{Abstract}

Introduction: Innovation in education should be done from the context and the factors that interfere in the construction and understanding of the curriculum. In the scope of nursing, teaching has undergone great changes in educational activities due to the demands of the capitalist world.

Objective: To analyze the curriculum advances, which are announced as innovative educational projects aiming vocational training in nursing in Brazil.

Methods: This is an integrative review of literature on curricular innovations and training of nursing students. The bibliographic survey was performed in the databases of Lilacs and Medline/PubMed using the following keywords: higher education, degree programs in Nursing and curriculum.

Results: We found seven articles that addressed on the profile and training of professional nurses and curriculum changes in the undergraduate course. It became evident that the curricular changes of course still happen gradually, and reflect political moments which often are not in line with the current health model conjecture.

Conclusion: Despite the curricular changes in nursing that happened due to socio-political movements, have not yet produced changes in
1 Departamento de Enfermagem. Faculdade de Juazeiro do Norte. Juazeiro do Norte, CE. Brazil.

2 Laboratório de Delineamento de Estudos e Escrita Científica. Faculdade de Medicina do ABC. Santo André, SP. Brazil.

3 Laboratório de Delineamento de Estudos e Escrita Científica. Escola Superior de Ciências da Santa Casa de Misericórdia de Vitória, EMESCAM. Vitória, Espirito Santo, Brazil.

4 Médico ortopedista do Hospital Regional do Cariri, Juazeiro do Norte, Ceará, Brazil.

5 Programa de Mestrado Profissional Ensino na saúde, CMEPES. Universidade Estadual do Ceará-UECE, Ceará, Brazil. Grupo de Pesquisa Vida e Trabalho, UECE.

Contact information:

Maryldes Lucena Bezerra de Oliveira.

Address: Faculty of Juazeiro do Norte, San Francisco Street, 1224A, Juazeiro do Norte, Ceará, Brazil.

Tel: (88) 2101-2777.

झmaryldeslucena@yahoo.com.br 
teaching that are sufficiently in line with the requirements of the job market and are able to prepare focused professionals in humanized and contextualized care and involved in the transformation of reality.

\section{Keywords}

Higher Education; Graduate

Programs in Nursing;

Curriculum.

\section{Introduction}

The discussion on "curriculum advances" get closer of the concept of "innovation", since both may represent an intentionality in response to the necessity with the participation and involvement of those who make the institutional team that takes the development of the curriculum and institutional.

Innovation in education needs to be done from the context and the factors that step in the construction and understanding of the curriculum. On this issue, Campolina e Martínez [1] remember that innovation does not arise at random and can't be treated as an isolated phenomenon, without consider the reality in which it is produced and the reflections built from a moving, an idea of world and society.

In this same direction, Faria e Fonseca [2] explains that innovation isn't an abstract one, because it happens at the certain time and place, being a product of human action. Being a human phenomenon, innovation historically brings to polysemy that needs to be considered, as clear as the understanding of the issue doesn't occur in error, away from the context and emptied of meaning [3].

The contact with the culture of "new" and "novelty" in today's society has been explored in many different kind of dimensions. This question has been addressed and it is necessary to watch out for the risk of terms such as "innovation" lose its meaning, rather than receive further consideration by those professionals who make the subject matter of education.

The author notes that in higher education, often the implementation of New Information and Communication Technologies, teacher training programs and curriculum reforms design are classified as innovative, when they are actually specific actions, far from the broad concept of innovation, which refers to a new educational and training proposal, which interferes in the institution as a whole and not only in isolated points [3].

The institutionalization of nursing as a teaching area occurred in 1922, at the same period it happened the advent of Brazilian nursing. From this moment, nursing education has undergone major changes in educational activities due to the demands of the capitalist world $[4,5]$.

In the subject matter of health policies the reports of the $8^{\text {th }}$ National Health Conference (CNS, Portuguese) breaks with the ordinary current paradigm biomedical and creates the National Health System from Brazil (SUS, in Portuguese). As for the training of professionals, the 9th CNS (in Portuguese) indicates the revision of curricula, adjusting them to the social realities, ethnic-cultural and epidemiological scenario, ensuring training with full integral vision and social commitment [6].

The seventies are marked by the University Reform of 1968 which caused the revision of the curricula of higher education in the country, giving rise to Opinion 163/72, which was in force until December 1994. This university reform materialized in the training of health professionals, with reference to the Flexner Report. Knowledge in basic cycle was offered by increasingly specialized departments, with little correlation with future professional practice, students experiencing the dichotomy between theoretical and practical content and could complete the degree with only Nursing knowledge notions on Public Health. There were 
three qualifications in order to undergraduate Nursing, which has lost its character of completion, and still Graduation [7].

In this same decade also marked by structure, cultural and corporate organization of Nursing, with the implementation of the first Master in Nursing, in Anna Nery Nursing School, in Rio de Janeiro, the creation of Nursing Councils and the first Professional Associations, which would give rise to unions [7].

The change of curriculum paradigm takes shape from March 1992, when the forwarded proposal received a favorable opinion from SENESu (in portuguese) and finally the "Minimum Content and Duration of Nursing Graduation Course" were set with the publication of the new Opinion CFE 314/94.

On December 20, 1996, thirty-five years after the promulgation of the first LDB (Directive and Basis Law in Brazil), it was published Law 9394/96 (new $L D B)$, the result of more than a decade of negotiations, demanding that all the current educational process in Brazil would fit to it. It is worth mentioning that the process of discussion to the new curriculum of nurses occurred in parallel, within the same principles, and was born with the spirit of the new LDB advocated.

At last, in October 2001 the CNE/CES 1133/2001 - National Guidelines of Graduate Nursing, Medicine and Nutrition is approved and, in November, the Resolution 3/2001 established the specific directives for the undergraduate education in Nursing [7].

In this context, one should consider the nurse profile defined in the DCN/ENF as an individual with general training, technical, scientific and humanistic knowledge, with critical and reflective capacity, prepared to act at different levels of care in the healthdisease scope, guided by ethical principles [8].

Thus, it is imperative the necessity to monitor how these guidelines have been understood and implemented in the educational proposal of institutions that train nurses in order to ensure humane health care, intended by the present moment in SUS. The curriculum should represent the world view observed by the school and their teachers.

This research set out to do a study related to professional training in nursing for the current society, considering the demands of this area of knowledge, discuss legal elements surrounding the nursing training process in brazilian society. Guiding question: which elements guide the pedagogical proposal concerning to the SUS (NHS, in English)? How are the future professionals being prepared to act in this contemporary society, which requires critical, reflective, enterprising, independent and generalist nurses, as recommended by the Nursing Curriculum Guidelines?

Thus, this study is justified by the need to analyze the training professional process of the nurse and discuss elements that involve the training process in brazilian society, as the basis for the support of a pedagogical proposal concerning to the SUS (Brazilian Health System). The goal is to analyze the curriculum advances that are announced in innovative educational projects for vocational training in Nursing in Brazil.

\section{Methods}

This is a integrative review compiled through the following steps: establishing the hypothesis and review of objectives; establishment of criteria for inclusion and exclusion of articles (sample selection); definition of the information to be extracted from selected articles; analyzing the results; discussion and presentation of results and; the presentation of revision [9].

To select the items a search was carried out in the databases PubMed and Lilacs. It was not considered the publication period because of lack of subject of studies in that theme. The search was performed using the integrated method, with the descriptors: higher education, degree programs in Nursing and curriculum. 
The criteria of inclusion for this review were: to address issues related to the Nursing curriculum and higher education, be articles and be published in Portuguese, English or Spanish. Thus, theses, dissertations and letter to the reader were excluded in this study. According to Figure 1, we found 15 articles addressing the theme of health education and, however, after reading the abstracts, articles were selected that addressed some analysis or ex-

Figure 1: Integrative review process.
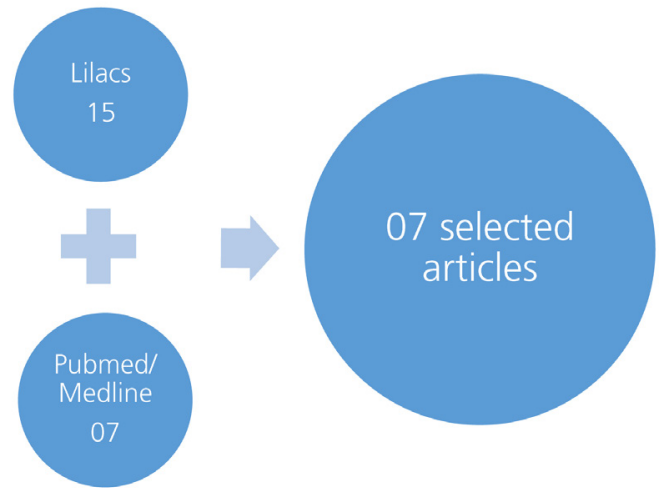
Table 1. Characterization
Reference
Correia LM, Henriques RLM,
Nogueira MFH, Pacheco AS, Romano RT. (2004) [7]

Freitas MAO, Seiffert OMLB. (2007) [10]

Oliveira MAO, Veríssimo MLOR, Püschel VA, Riesco MLG. (2007) [11]

Lopes Neto D, Teixeira E, Vale EG, Cunha FS, Xavier IM, Fernandes JD et al. (2008) [4]

Barbosa ECV, Viana LO. (2008) [12]

Lima JOR, Esperidião $E$, Munari DB, Brasil VV. (2011) [13]

Teixeira E, Fernandes JD, Andrade AC, Silva $\mathrm{KL}$, Rocha MEMO, Lima RJO. (2013) [14] perience of curricular innovation of Nursing, for a total of seven articles. After this stage, it began the reading of the articles to later organize them.

The following articles were organized in the table, which illustrates the characterization of items such as the year of publication, scientific journals, research objectives, as well as the evidence of the studies.

\section{Results}

The distribution of the manuscripts is described in tables and figures, as shown next. There were found seven articles that addressed on the profile and training of professional nurses and curriculum changes in the undergraduate course. It was evident that the curricular changes of course still happen gradually, and reflecting political moments which often end up not concerning with the current health model assumptions. Tables 1 to $\mathbf{3}$ and Figure $\mathbf{2}$. 
Table 2. Analysis of the manuscripts in relation to curriculum advances, 2016.

\section{Reference}

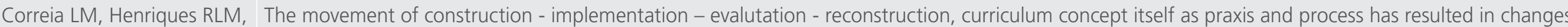
Nogueira MFH, Pacheco AS, in the structure and curriculum.

Romano RT. (2004) [7]

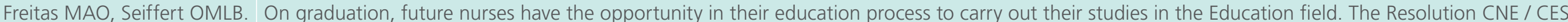
(2007)1 [10]

No. 3 (4) of 7 November 2001, establishing the National Curriculum Guidelines of Graduate Nursing, provides in its Article 6 section III , paragraph " $d$ " relevant content to pedagogical training of nurse who will give you support to plan, implement and participate actively in the training of other professionals, and education and health promotion programs.

Oliveira MAO, Veríssimo

MLOR, Püschel VA, Riesco

MLG. (2007) [11]

We recognize the academic character of the training curriculum, because we know that we are talking about something that belongs to the world of education, although we have reference to the work field. We identify research as a tool of the educational process of the nurse and want the student's learning organized according to the clinical and epidemiological reasoning, which have great relevance for the professional working. We believe that the student is the subject of the initial training process with autonomy and active participation in the curriculum.

Lopes Neto D, Teixeira E, Vale EG, Cunha FS, Xavier IM, Fernandes JD et al. (2008) [4]

Barbosa ECV, Viana LO. (2008) [12]

The DCN and PPC take priority on the agenda of higher education. However, it's not only to set the DCN, you must implement them; not just develop PPC, you must implement them with adherence to DCN; not just expand higher education, it is necessary to access it in search of quality and commitment to social justice and the scientific and technological innovations

These guidelines have to meet the health policies and are in accordance with the Ministries of Health and Education, which propose the reorientation of undergraduate courses in this area, providing technical, operational and financial cooperation so that these courses can develop a joint work with management, including the SUS services and the general population, which is recognized as partnership programs of these ministries - EDUCARSUS APRENDERSUS and ENSINASUS from 2004

Lima JOR, Esperidião E, Munari DB, Brasil VV. (2011)1 [3]

The need for investment in training of health professionals under the ethical- humanist perspective is essential for the consolidation of SUS. Any citizen, provided user of health services, public or private, can realize the necessity of a better qualify health workers, as their difficulties in answering questions inherent in the humanistic principles in their everyday life.

Teixeira E, Fernandes JD

The expansionist policy of higher education, implemented in Brazil in the last decades, reflecting therefore the market demands and pressure from civil Andrade AC, Silva KL, Rocha society groups to open new courses and, in this scenario, there is the possibility of higher education at night and in distance mode.

MEMO, Lima RJO. (2013)

[14] 
Table 3. Affective aspects members of the current teaching and learning process.

\section{Reference}

Correia LM, Henriques RLM, Nogueira MFH, Pacheco AS Romano RT. (2004) [7]

Freitas MAO, Seiffert OMLB (2007) [10]

Oliveira MAO, Veríssimo MLOR, Püschel VA, Riesco MLG. (2007) [11]

Lopes Neto D, Teixeira E, Vale EG, Cunha FS, Xavier IM, Fernandes JD et al. (2008) [4]

Barbosa ECV, Viana LO. (2008) [12]

Lima JOR, Esperidião E, Munari DB, Brasil VV. (201 [13]

Teixeira E, Fernandes JD Andrade AC, Silva $\mathrm{KL}$, Rocha MEMO, Lima RJO. (2013) [14]

\section{Aspects}

The interdisciplinarity in health education involves disciplinary integration - integrated-curriculum around problems arising from the health reality where the disciplines that help in the understanding of that context interact dynamically establish connections with each other and mediations. In this proposal, the principle of hierarchy among the sciences is replaced by the principle of cooperation, allowing the internal transitivity between science fragments, concepts and languages. The society's vision is plural in search of historical changes, political and economic able to overcome the strong social inequalities.

Debates and studies show the need to establish in higher education, active learning processes that encourage autonomy, creativity and criticality of students. In this sense demand the consolidation of training spaces that encourage future learning and coping with problems and challenges in the context of professional practice. To face this challenge requires taking as reflection of focus and questioning the teaching work at the prospect of qualifying vocational training of higher level.

We are also talking about the relationship between education and work, in particular political, economic, cultural, national and also international context of globalized problems. It is this common perspective we try to see how it will show in the future initial training in nursing, which will be your challenges. The learning process, which involves teacher and student in acquisition of knowledge and practices necessary to nursing work, cannot be taken off this look to the future.

The evaluation has become fundamental part in ensuring the implementation of the DCN/ ENF as a guiding activity for the development of innovative PPC, ensuring student centered learning; building an integrated curriculum, in which the axis of the training becomes the practice/ work/ nursing care; the articulation theory/ practice; health concepts while living conditions; the presence of cross-cutting issues; the concept of evaluation as a tool to (re) definition of paradigms.

You can change the logic of the traditional teaching focused on the teacher and/ or in educational technology, i.e. it is feasible to diversify the educational setting so that it will be multi reference through active teaching and learning methodologies and articulate educational institutions and services, teachers and students in order to promote intercourse experiences of the same institution of higher education or between them.

In all this change is essential that the teacher is prepared for both the specific skills of your area, as also to the relational skills that can promote or hinder the desired learning because the teacher becomes no longer the transmitter, but the mediator to achieve knowledge.

By the time it is necessary to increase the number of nurses in the country, we shouldn't also neglect the academic quality parameters, i.e. that these professionals are trained in recognized quality courses that can train nurses profile and competence to meet the real health requirements of the population. 
Figure 2: Current professional profile of nurses. * prepared by the authors.

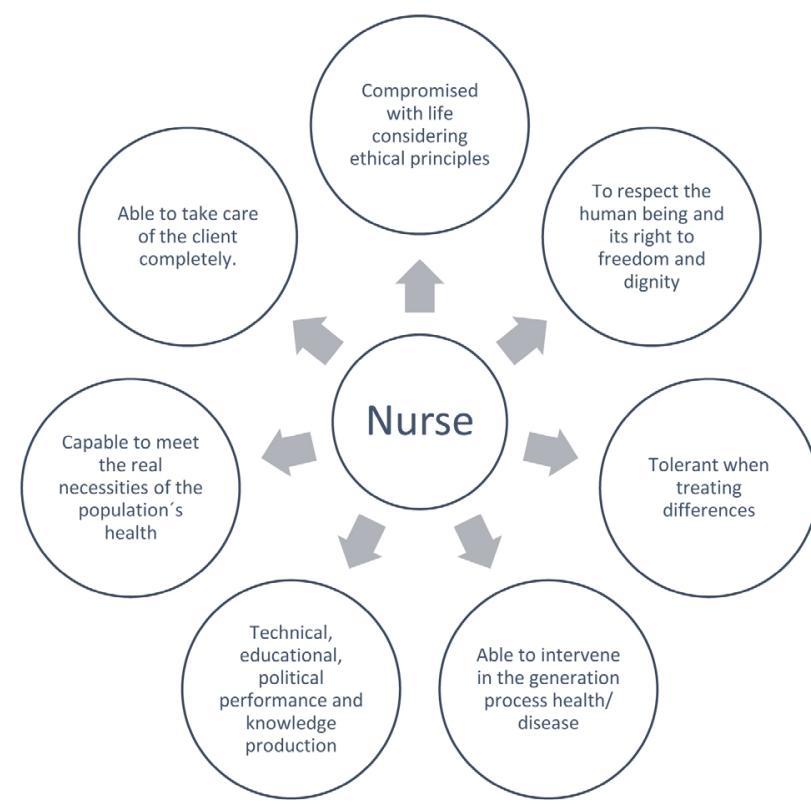

- Committed to life from ethical principles

- Respect the human being in their right to freedom and dignity

- tolerant in dealing with differences

- Able to intervene in generating health / disease process

- Technical Expertise, educational, political and knowledge production

- Competent to meet the real health needs of the population

- Able to look full of your client.

\section{Discussion}

The production of knowledge for completeness, resulting from the knowledge and the health education practices, requires a theoretical construct contextualized in ease of movement, desire and transformation movement, able to weave the concrete experience of life that gives it birth and life which will lead to 13.

From the integration of cross-cutting issues in the curriculum, this becomes more flexible and frank, considering that the issues can be prioritized and contextualized according to the local and regional situation and other issues may also be included [15].

Brazilian training in health, over time, progresses towards meeting the political guidelines of the health sector, especially if we think of the requirements imposed by the implementation of the
Unified Health System (SUS). However, the political imposition, even though arising from social movements, which have shaped the field of public policies in the sector, does not guarantee the change movement in training [16].

The institutionalization of nursing as a teaching area occurred in 1922, at the same time it happened the advent of Brazilian nursing. Since that time, nursing education has undergone major changes in educational activities due to the demands of the capitalist world. In 1961, the Guidelines and Bases of National Education were fixed and the Federal Education Council was created with the power to set the minimum curricula of the courses.

But it was in 1996 that the Law of Guidelines and Bases of National Education - LDB was established and the board was renamed the National Council of Education. This council had the competence to define the National Curriculum Guidelines - DCN courses [4.5].

Concerning the vocational training, the DCN guide nursing education to the Health System's needs in order to recommend that nurses should be able to know and act on the problems and situations most prevalent health-disease in the national epidemiological profile with a profile generalist, humanist, critical and reflective, with scientific and intellectual rigor, based on ethical principles [17].

The DCN indicate a path: more flexible rules and, even so, favoring the construction of major commitments of higher education institutions as SUS18. From the National Curriculum Guidelines for Nursing Graduate Course (DCENF), CNE/SES 3 of 7 November 2001, it began a restructuring process in the curricular organization, didactic and pedagogical, toward change in the training process of the nurse.

This process must be permeated by the ethical dimension of daily tasks, built from critical thinking, reflection, social analysis and the subject of relationships in a concrete reality. Otherwise, any change of strategy based on DCENF, would be abstract and insufficient [19]. 
After the time of compliance with the DCN and SUS, nursing teaching lives intense debate in the search for strategies that allow to power the production of novelty and inventiveness to professionals. Thinking about the teaching management in health exposed to all health sector needs suggests, as necessary, the analysis of what has been proposed in the academic scene and also what has been possible to carry on the work and social participation of the sector. When it specifically comes to the health care process, it is expected that this training learns to take into account the other, the scientific knowledge serve mainly to account for the uniqueness of the moment of encounter caregiver assumes (recognizing that clinical act on health reflects a therapy that is effective in meeting the individuals) [16].

In this context, one should consider the nurse profile defined in the DCN / ENF as an individual with general training, technical, scientific and humanistic, with critical and reflective capacity, prepared to act at different levels of care of the healthdisease, guided in ethical principles [8].

The development of such skills and abilities requires the adoption of strategies based on SUS guidelines, the broader concept of health and the use of active teaching and learning methodologies. In this process, the proposed activities considered as structure multidisciplinary work, the integration of education and the demands of services and improvement of comprehensive health care of the population.

They also provide the development, in the training process, of the ability to learn, which includes learning to know how to do to live together and ensuring the training of professionals with autonomy and discernment to guarantee comprehensive care health quality and resoluteness [4].

Has consciousness, as educators, about the commitment to future professional nurses' preparation which in addition to skill in the art and Human Care, and attuned to the social role of nursing, there are also ethical citizens committed with themselves and with each other and able to act in a society imbued with uncertainty [20].

To follow the guidance of regulatory instruments, in this case the DCN, stands out from the document what is expected of a professional in the nursing field, starting by defining the CNE resolution / CES No 03/2001, for the graduate's profile.

Throughout the text of the DCN, perceives itself the intention to form a professional that meets the health field requirements with initiative, reflection, motivation, leadership, and capable to act with competence and professionalism in all health care areas. It is expected that professionals are able to deal with the complexity, surprises and the news that the real world presents daily; so we need to bet on proposals for learning that go beyond training and formality. We have to create conditions for Continuing Education at work, in the personal life, exercising care and citizen behavior.

In the context of the standardizations Curriculum Guidelines for graduate students in any area in Brazil, as basic guidelines for the preparation of future professionals fall in the group of those who prepare their professionals through higher education. Being an official document the National Curriculum Guidelines are announced in the new perspective through the easing of technical and scientific training, know-how and know-think.

While that seek answers to many questions, it is important to be aware that both the PPC (Educational Project Course) and the Curricular Guidelines for Nursing cannot account, in full, the complex network visible and invisible that permeates the care of nurses. It is noted a great challenge for teaching undergraduate nursing because, while there is need to train a generalist, it is also necessary to consider political and economic issues, meeting with competence and visibility, the various specializations that arise continually in the health care scenario [20].

As Expression of that, Noteworthy is the Movement of educational institutions, significant Where Changes Also are underway in search of joint edu- 
cation, organized service and Movements of Population in perspective to contribute to the Health Professional Training, especially nurses.

In this sense, the UNI Project (New Initiative in Training of Health Professionals), the VERSUS (Experience Stage in the National Health System Reality), the Pro-Health (National Program for Reorientation of Vocational Training in Health), the learn- (SUS SUS and the undergraduate courses in the health field), and proposals for deployment pathway, as the PET-Health (Education Program at Work for Health), are significant examples of the approach attempt Between teaching, service and Community by achieving advances and articulated pedagogical projects with Health Practices and Principles SUS [21].

It starts with the que Perspective These advances stem from the will of Understanding hum pace Rapidly Changing of confrontation between different social interests. Thus, the curriculum advances represent the desire, the commitment and hope to contribute to what the Vocational Training to deliver better context of coping in crisis conditions [22].

Masetto [3] warns about the idea, in our century, of the Brazilian university system still following European Universities Standards. However, the Society of Knowledge and Technology, requires Increasingly Professional Innovations, so a necessity for qualification and acquisition of more knowledge.

The finding is accelerated and disorderly growth courses and offer Undergraduate Nursing vacancies without due Monitoring YOUR Quality indicates the need for additional studies on Education in Nursing in Brazil [14]. So, the expansionist policy of Higher Education, implemented in Brazil in recent decades reflects therefore as market demands and pressures of groups of society paragraph civilians opening new courses and in this scenario, highlight the possibility of training no upper nighttime mode and the distance [14].

To follow the changes resulting from constant changes in political, social and economic situation of Brazil, it is necessary that nursing as a profession active in this new social context and health, to rearrange, in order to advance not only in training a new professional, but mainly of a critical individual can contribute to the transformation of the context in which it appears $[23,24]$.

Successive curriculum changes in undergraduate courses in nursing are not usually preceded by an analysis of the professional reality of nurses, and have not undergone assessments about their impact, as in the literature are found few follow-up studies graduates of universities in order to identify the weaknesses and strengths of training, so that thus we can reflect on changes that still need to be implemented [25].

According to Article 3 of the National Curricular Guidelines (DCN), the Graduate Program in Nursing, in general, should aim at the formation of the generalist nurse, humanist, critical and reflective. In this perspective, it is expected that this professional is able to understand and intervene in problems and health situations and most prevalent disease in the national epidemiological profile, with emphasis on its area of operation, valuing the biopsychosocial dimensions of human life and its determinants [7]. In addition, the nurse about to graduate should be able to act with a sense of social responsibility and commitment to citizenship, as promoter of integral health of the human being [26].

This study is important as education is understood as a basic tool for the transformation of health work and education processes, of which nursing is an integral part, resulting in a reinterpretation of concepts and attitudes to produce a workforce able acting in accordance with the requirements and purposes of the profession [26, 27].

In the 1980s, organized civil society spurred several movements that resulted in the promulgation of the new Constitution of the Federative Republic of Brazil in 1988 and the approval of the Organic Law of Health (Loss) - Law No. 8080/90 and Law 8,142/90 creating the Unified Health System 
(SUS) and establishing the integrity of health care as the guiding constitutional principle of formulating health policies.

The LOSs reaffirm that effective public health policies will give the reorientation of human resources policy at the NHS and therefore in the reformulation of the curricula of higher education institutions through appropriate curriculum guidelines to the needs of SUS [4]

The changes in the field of education policies contributed to the (re) design in health practices and a breakthrough was provided by DCN for training in the area. In the case of nursing, in particular contributing to the profession to authorize it to take another role with the health needs of the population [28].

The theoretical and practical fragmentation of the ethical dimension of care was highlighted as a weakness found in the training process. There remain gaps between theoretical contents and actions in practical experience. This paradox confuses and slows to overcome the challenges of a guided training in ethics [29].

There is a strong influence of the nurse's training process in their professional practice in the world of health work, since their knowledge, skills and competences (professional profile) are made from the training graduation. How is this process can generate positive or negative consequences for both professional as to the quality of health care provided by him [30]?

The education sector has gone through many crises, expressed, above all, because of the contrast between the hegemonic conceptions, which have a pedagogy of transmission of content or criticalsocial content, and constructive-interactionist conceptions sustained: the reality of questioning, the joint theory and practice, interdisciplinarity, the active student participation in the process of teaching and learning, an appreciation of cultural diversity, the individual historicity and its integration into everyday life [16].
When you think, so an undergraduate degree in nursing, is rescued these theoretical, historical and conceptual frameworks. Important elements, from a political point of view, that put us undoubtedly in a new scenario in the field of health education, but, likewise, do not guarantee the solution to the many problems we still have in educational practices. The inclusion of other modes again requires a willingness and openness to a "no yet know," a graduate teaching proposal willing to novelty [16].

It is a great challenge to continue-evaluating and improving the quality of curricula of higher education for the nursing actively participated in the transformation process of the health scenario in Brazil, and that the training goes beyond the academic and technical issues, but to serve as strategy for social transformation [21].

Because of the low number of jobs related to the training of nurses, the need for further research to assist in the process of knowledge of the weaknesses and strengths of vocational training, best directing in Brazilian nursing graduate education is pointed, contributing to strengthening the profession.

\section{Conclusion}

It is observed that despite the curricular changes in nursing that happened due to socio-political movements, have not yet produced changes in teaching that are sufficiently in line with the requirements of the labor market and are able to prepare focused professionals in humanized care and contextualized, and involved in the transformation of reality.

\section{References}

1. Campolina LDO, Martínez AM. Fatores favoráveis à inovação: estudo de caso em uma organização escolar. Revista Psicologia Organizações e Trabalho, 2013; 13(3), 325-338.

2. Faria MFB, Fonseca MVA. Cultura de Inovação: Conceitos e Modelos Teóricos/Culture of Innovation: Concepts and Theoretical Models. Revista de Administração Contemporânea, $2014 ; 18(4), 372$. 
3. Masetto MT. Inovação curricular no ensino superior: organização, gestão e formação de professores. In Masetto MT. (Org.) Inovação no ensino superior. São Paulo: Loyola, 2012.

4. Bezerra IMP, Sorpreso ICE. Concepts and movements in health promotion to guide educational practices. J Hum Growht Dev, 2016; 26(1):11-20..

5. Oguisso T, Freitas GF. Brazilian nursing history on the shoulders of giants. International nursing review, 2015; 62(1), 75-81.

6. Veiga IP. Relatório Final da $9^{a}$ Conferência Nacional de Saúde. Brasília (DF), Brasil: CNS/MS; 1993.

7. Correia LM, Henriques RLM, Nogueira MFH, Pacheco SA, Romano RT. Construção do projeto político pedagógico: experiência da Faculdade de Enfermagem da UERJ. Rev Bras Enferm, 2004; 57: 649-53.

8. Tonhom SFDR, Costa MCGD, Hamamoto CG, Francisco AM, Moreira HM, Gomes R. Competency-based training in nursing: limits and possibilities. Rev Esc Enf USP, 2014; 48(SPE2), 213220.

9. Bezerra IMP, Machado MFAS, Souza OF, Antão JYFL, Dantas MNL, Reis AOA, Martins AAA, Abreu LC. Professional Activity in The Context of Health Education: A Systematic Review. J Hum Growth Dev 2014; 24(3): 255-262.

10. Freitas MAO, Seiffert OMLB. Formação docente e o ensino de Pós-Graduação em Saúde: uma experiência na UNIFESP. Rev Bras Enferm; 60(6): 635-640, nov.-dez. 2007.

11. Oliveira MAO, Veríssimo MLOR, Püschel VA, Riesco MLG. Desafios da formação em enfermagem no Brasil: proposta curricular da EEUSP para o bacharelado em enfermagem. Rev Esc Enferm USP; 41(n. esp): 820-825, dez. 2007.

12. Barbosa ECV, Viana LO. Um olhar sobre a formação do enfermeiro/docente no Brasil. Rev. enferm. UERJ; 16(3): 339344, jul.-set. 2008.

13. Lima JOR, Esperidião E, Munari DB, Brasil VV. A formação ético-humanista do enfermeiro: um olhar para os projetos pedagógicos dos cursos de graduação em enfermagem de Goiânia, Brasil. Interface comun. saúde educ; 15(39): 1111-1126, out.-dez. 2011.

14. Teixeira E, Fernandes JD, Andrade AC, Silva KL, Rocha MEMO, Lima RJO. Panorama dos cursos de Graduação em Enfermagem no Brasil na década das Diretrizes Curriculares Nacionais. Rev Bras Enferm; 66(spe): 102-110, set. 2013.

15. Bomfim AMD, Anjos MBD, Floriano MD, Figueiredo CSM, Santos DAD, Silva CLDCD. Parâmetros curriculares nacionais: uma revisita aos temas transversais meio ambiente e saúde. Trab. educ. saúde, 2013; 11(1), 27-52.

16. Chaves SE. Os movimentos macropolíticos e micropolíticos: no ensino de graduação em Enfermagem. Interface (Botucatu). 2014; 18(49):325-336.

17. Almeida ML, Peres AM. Conhecimentos, habilidades e atitudes sobre a gestão dos formados de enfermagem de uma universidade pública brasileira. Invest Educ Enferm, 2012; 30(1): 66-76.

18. Costa RKDS, Miranda FAN. The National Health System and of Family in nurse's academic education. Rev Bras Enf, 2009; 62(2), 300-304.
19. Fernandes JD, Rosa DOS, Vieira TT, Sadigursky D. Dimensão ética do fazer cotidiano no processo de formação do enfermeiro. Rev Esc Enferm USP. 2008; 42(2): 396-403.

20. Corbellini VL et al. Nexos e desafios na formação profissional do enfermeiro. Rev. bras. enferm. 2010; 63(4):555-560.

21. Silva MJ, Sousa EM, Freitas CL. Formação em enfermagem: interface entre as diretrizes curriculares e os conteúdos de atenção básica. Rev Bras Enferm, Brasília 2011 mar-abr; 64(2): 315-21.

22. Villa MD. Reforma curricular: elementos para el estúdio de sus tensinones. In Ângulo R, OROZCO, Bertha. (Coord.) Altenativas metodológicas de intevención curricular en la educación superior. México: Plaza y Valdez, 2007.

23. Machado LDS, Ramos JLS, Machado MDFAS, et al. Participatory process of health promotion at school. J Hum Growth Dev, 2015; 25(3):357-363.

24. Souza JCD, Lima JDOR, Munari DB, Esperidião E. Teaching of the humanized care: evaluation and trends of the scientific production. Rev bras enf, 2008; 61(6), 878-882.

25. Spagnol CA, Fortuna CM, Villa EA, Velloso IS, Salviano ME. Care in nursing in Brazil. Recherche en soins infirmiers, 2015; (122), 82-89.

26. Ministério da Educação (Br). Conselho Nacional de Educação. Resolução CNE/CES $n^{\circ}$ 3, de novembro de 2001. Institui Diretrizes Curriculares Nacionais do Curso de Graduação em Enfermagem [internet]. Brasília (DF): CNE; 2001.

27. Ito EE, Peres AM, Takahashi RT, Leite MMJ. O ensino de enfermagem e as diretrizes curriculares nacionais: utopia $\mathrm{x}$ realidade. Rev esc enferm USP, 2006; 40: 570-5.

28. Lopes Neto D, Teixeira E, Vale EG, Cunha FS, Xavier IDM, Fernandes JD, Bocardi MIB. Adherece of Nursing Graduation Courses to the National Curricular Guidelines. Revista brasileira de enfermagem, 2007; 60(6), 627-634.

29. Bordignon SS, Lunardi VL, Dalmolin GL, Tomaschewski JG, Filho Lunardi WD et al. Questões éticas do cotidiano profissional e a formação do enfermeiro. Rev Enferm UERJ. 2011; 19(1):94-9

30. Pires AS, Souza NVDO, Penna LHG, Tavares KFA, D'oliveira CAFB, Almeida CM. A formação de enfermagem na graduação: uma revisão integrativa da literatura. Rev enferm UERJ, Rio de Janeiro, 2014 set/out; 22(5):705-11.

\section{Publish in International Archives of Medicine}

International Archives of Medicine is an open access journal publishing articles encompassing all aspects of medical science and clinical practice. IAM is considered a megajournal with independent sections on all areas of medicine. IAM is a really international journal with authors and board members from all around the world. The journal is widely indexed and classified Q1 in category Medicine. 